\title{
THE DOCTORATE IN SOUTH AFRICA
}

\author{
TRENDS, CHALLENGES AND CONSTRAINTS
}

\section{Johann Mouton}

\section{INTRODUCTION}

We have witnessed over the past decade a renewed interest in doctoral education in South Africa. This interest has been fuelled by national as well as institutional policies that have identified the production of doctoral graduates as a matter of strategic priority. The country needs more doctoral graduates both to replenish the academic capacity in the higher education sector and to serve the knowledge economy and its new challenges.

The aim of this chapter is to argue that four policy discourses have shaped and continue to shape current debates on the production of PhDs in South Africa. These discourses address the need for increased volumes of PhD output (growth), efficiency, transformation and quality. But these discourses are not simply separate and parallel 'forces' that have differential impacts on doctoral production in South Africa. These discourses are often at odds with one another; they co-exist - often in tension - and sometimes even seem contradictory when taken together. The pursuit of increased numbers (growth) may, for example, have a negative impact on the achievement of quality and even compromise efficiency. These discourses - and the imperatives embedded in them - operate in a complex (higher education) system of recursive causality (feedback loops) and emergent properties (different levels of impact).

The four discourses (Figure 4.1) capture the ecology (the external demand and accountability environment) of doctoral education and training in South Africa today. The diagram suggests that there are four sets of factors or forces that together create a unique demand and accountability regime that exerts various pressures on the universities, and specifically on their academic staff. Figure 4.1 also suggests that some of these external demand factors are global and international (such as 


\section{PART ONE • FROM THE GLOBAL TO THE LOCAL}

rankings), while some are more local and internal (such as the role of the Department of Higher Education and Training funding framework). In general, the factors are mutually reinforcing, which means that the end result is a powerful discourse of demand and accountability at every level of the system.

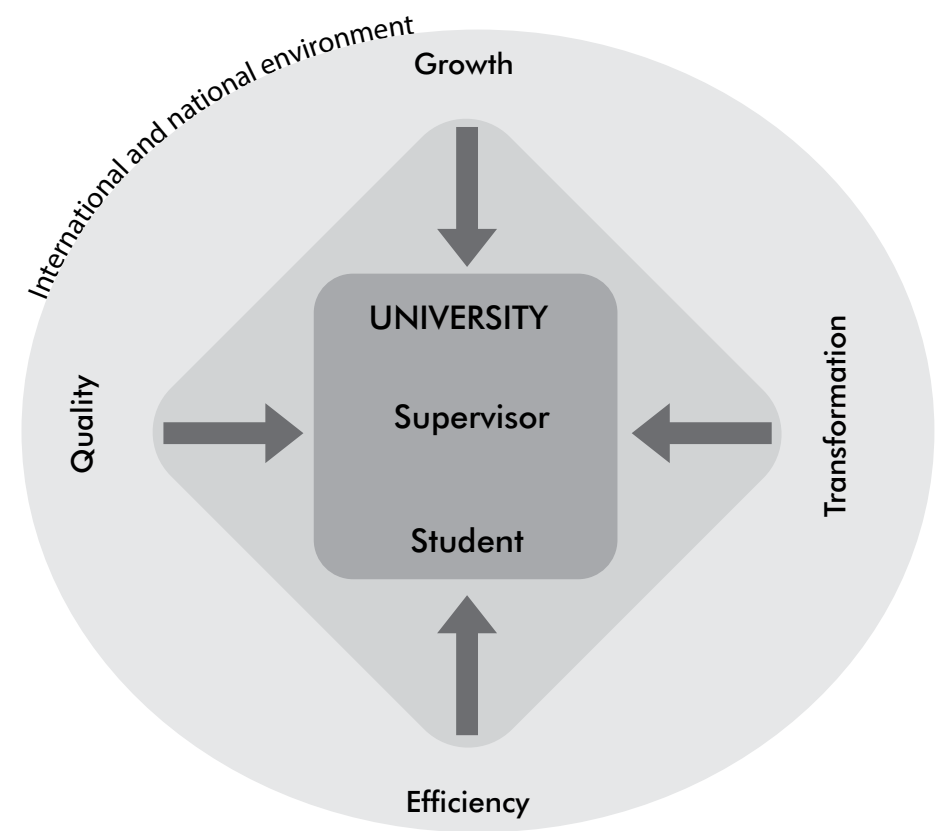

FIGURE 4.1 The four discourses underpinning doctoral production in South Africa

The second part of the diagram shifts the perspective to the supply side: the university, and specifically academic staff and supervisors. From this perspective, the demands are often experienced as contradictory and unreasonable. The demand for increased output and production of doctoral students is often considered to happen at the expense of quality. In addition, there has always been a clear tension between the demands for efficiency and equity (transformation) in education discourse in South Africa. We now turn to discuss each of these discourses in more detail.

\section{THE DEMAND FOR GROWTH}

Despite the absence of a coordinated policy focus, a strong emphasis on the production of more doctoral graduates emerged in the post-2008 period. For a start, the Department of Science and Technology set initial targets for PhD production, as described in its Ten-Year Innovation Plan: "To build a knowledge-based economy positioned between developed and developing countries, South Africa will need to increase its $\mathrm{PhD}$ production rate by a factor of about five over the next 10 to 20 
years" (DST 2008:29). In 2010, the ASSAf study proposed, amongst other things, an escalation of the number of graduates, increased funding for full-time doctoral students, targeting specific institutions with capacity to produce more $\mathrm{PhDs}$, and advocating for public support amongst the public for a better understanding of the value of the PhD (ASSAf 2010:17-18).

The National Development Plan echoes many of ASSAf's recommendations, but with much more specific targets, such as the aim of producing more than 100 doctoral graduates per one million of the population by 2030. This would translate into 5000 per annum in 2030 (compared to the latest output of 2258 in 2014). Both ASSAf and the National Planning Commission agree on the need for more doctoral graduates.

Before focusing on recent increases in the number of $\mathrm{PhD}$ graduates it is useful to take a more long-term view. Utilising a variety of historical sources, it was possible to reconstruct the long-term trends in doctoral output since the 1920s for South Africa (Figure 4.2).

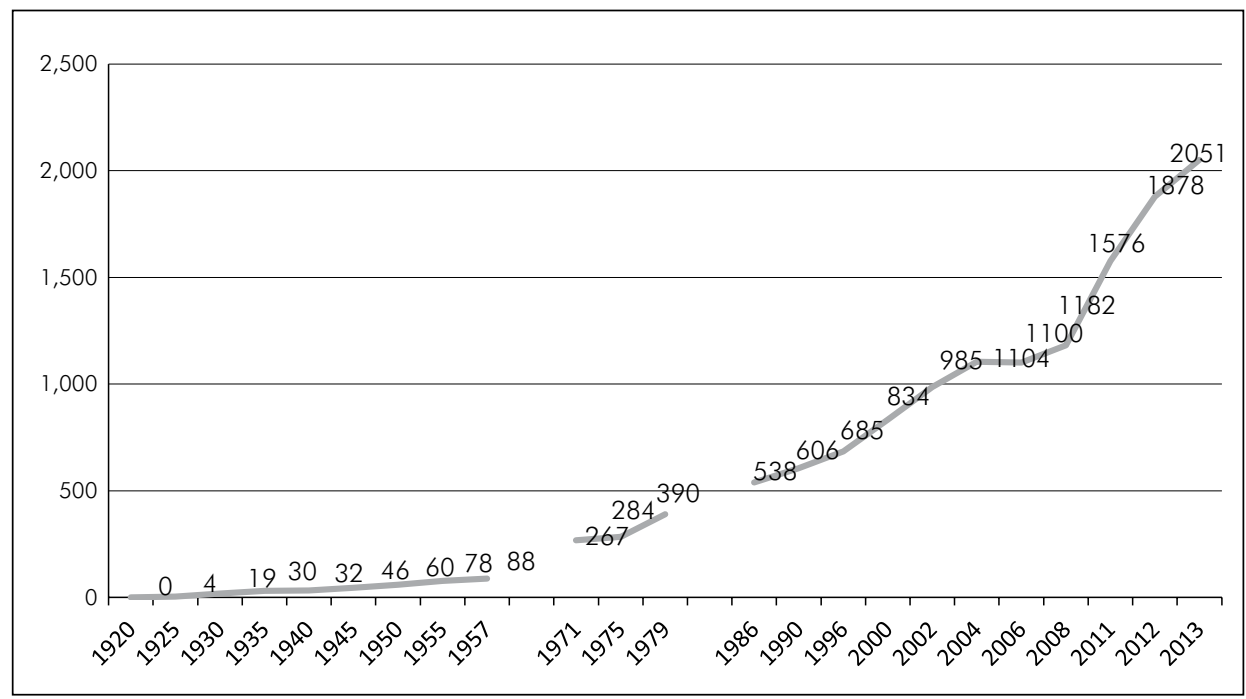

FIGURE 4.2 Growth in PhD graduates in South Africa (1920-2013) (Sources: Garbers 1960; DNO 1982; DoE 1999; DHET 2013a)

The long-term trends show a steady increase over time in the production of doctoral graduates. But it also shows a steep increase since around 2008. Figure 4.3 presents the more detailed data for the past two decades. Doctoral enrolments and graduations increased by an average annual rate of $6.4 \%$ between 1996 and $2012 / 13$ - a rate higher than any other degree level. 


\section{PART ONE • FROM THE GLOBAL TO THE LOCAL}

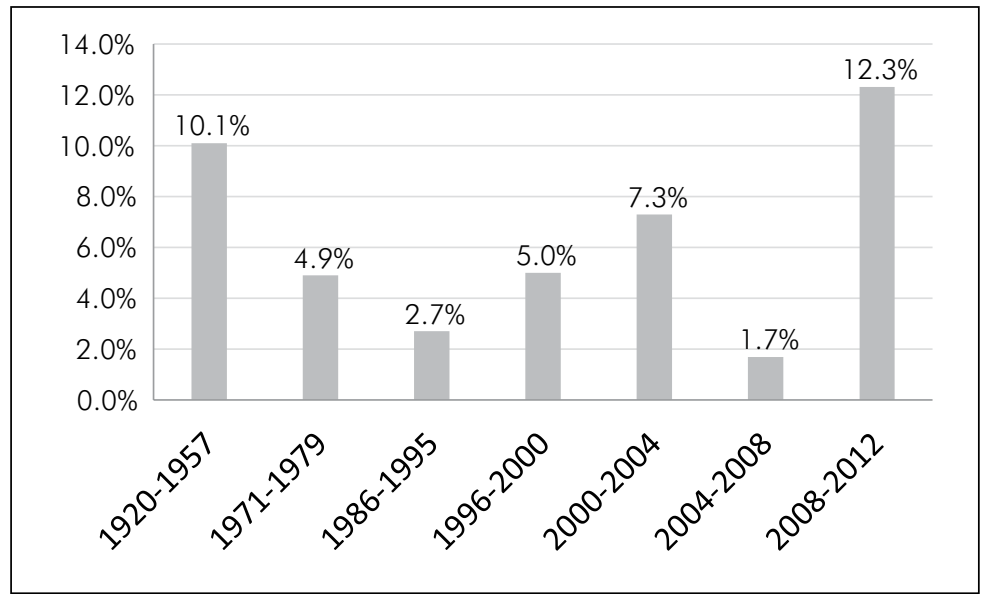

FIGURE 4.3 Average annual growth rate of PhD graduates (1920-2012)

The revision of the Department of Higher Education and Training research subsidy framework in 2003, which came into effect in 2005, for the first time included subsidies for postgraduate students, research masters and doctoral students. Most universities knew in 2003 that these changes were imminent. If one keeps in mind that the average doctoral degree in South Africa takes five years to complete, it is not surprising that the first effects of the revised subsidy framework would become evident by 2008 .

It is important, however, to remind ourselves that the policy discourse - at least as captured in the White Paper on Science and Technology (1996) - did not 'demand' growth per se but also advocated for increased numbers of graduates in the fields of science, technology and mathematics. The statistics show that South African universities as a group have in fact been quite successful in achieving the aim of increasing the number of doctoral graduates in specific fields. The proportions of doctoral graduates in science, engineering and technology, and in the business, economic and management sciences have increased considerably over the period 1996 to 2012. For example, the percentage of graduates in natural sciences, engineering and technology (SET) increased from 45\% in 1996 to $53 \%$ in 2012 (Figure 4.4). 


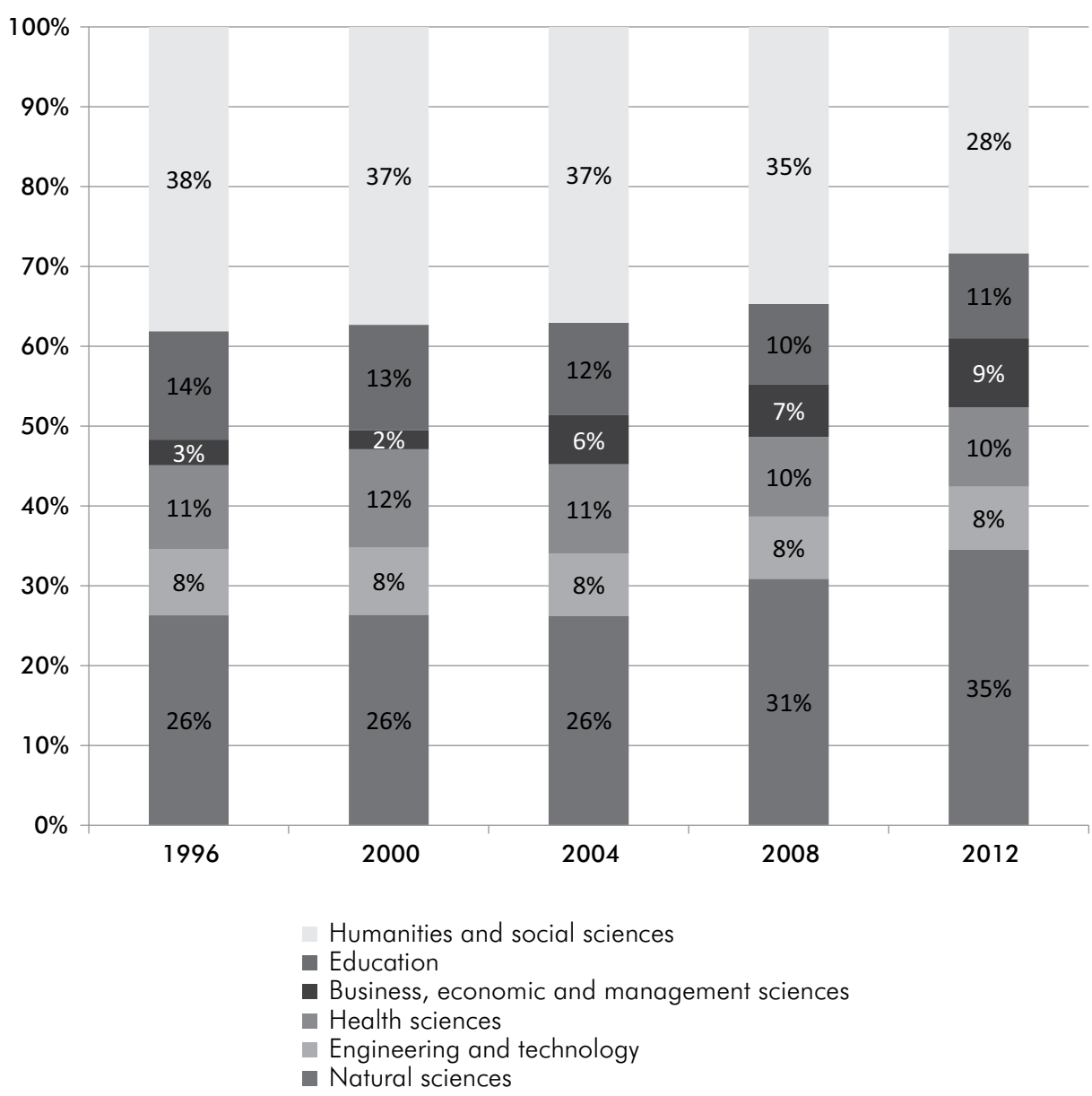

FIGURE 4.4 Average shares of the doctoral graduates in the various fields of study (19962012) (Sources: DoE 1999; SAPSE; DHET 2013; HEMIS data 2000-2012)

When comparing South Africa's yield of PhDs to that of other countries worldwide, the data reiterate the finding of the ASSAf (2010) PhD study that the country's production of $\mathrm{PhD}$ graduates is too low, and that South Africa is near the bottom of the list of $\mathrm{PhD}$-producing countries worldwide. In summary, when compared to Organisation for Economic Co-operation and Development countries, South Africa not only fares poorly against countries with a similar population size and GDP ranking, but even does so when compared to much smaller countries with lower GDP rankings, and fares considerably worse when compared to top-ranked GDP countries (Table 4.1). 
PART ONE • FROM THE GLOBAL TO THE LOCAL

TABLE 4.1 Comparison of South Africa with countries on key PhD indicators

\begin{tabular}{|l|r|r|r|l|l|}
\hline Country & $\begin{array}{l}2011 \\
\text { SET PhD } \\
\text { graduates } \\
\text { as \% of all } \\
2011 \mathrm{PhD} \\
\text { graduates }\end{array}$ & $\begin{array}{l}\text { Average } \\
\text { annual } \\
\text { growth rate } \\
\text { in total PhDs }\end{array}$ & $\begin{array}{l}\text { Population } \\
2000-2011\end{array}$ & $\begin{array}{l}2011 \text { SET PhD } \\
\text { graduates } \\
\text { per 100 000 } \\
\text { of 2011 } \\
\text { population }\end{array}$ & $\begin{array}{l}2011 \\
\text { total PhD } \\
\text { graduates } \\
\text { per } 100000 \\
\text { of 2011 } \\
\text { population }\end{array}$ \\
\hline Australia & $58.4 \%$ & $4.7 \%$ & 22324000 & 15.9 & 27.2 \\
\hline Canada & $62.8 \%$ & $3.3 \%$ & 34483980 & 10.3 & 16.5 \\
\hline Finland & $61.2 \%$ & $-0.2 \%$ & 5388272 & 21.1 & 34.4 \\
\hline Germany & $72.5 \%$ & $0.5 \%$ & 81797670 & 24.2 & 33.4 \\
\hline Ireland & $64.1 \%$ & $10.1 \%$ & 4576748 & 20.3 & 31.6 \\
\hline South Korea & $59.7 \%$ & $6.0 \%$ & 49779440 & 14.0 & 23.4 \\
\hline Norway & $63.9 \%$ & $6.4 \%$ & 4953000 & 16.7 & 26.2 \\
\hline Portugal & $52.1 \%$ & $3.5 \%$ & 10557560 & 11.4 & 21.9 \\
\hline Switzerland & $68.5 \%$ & $2.2 \%$ & 7912398 & 30.1 & 44.0 \\
\hline Turkey & $55.7 \%$ & $7.4 \%$ & 73950000 & 3.5 & 6.3 \\
\hline United Kingdom & $59.9 \%$ & $5.1 \%$ & 61761000 & 19.5 & 32.5 \\
\hline United States & $55.4 \%$ & $4.5 \%$ & 311591900 & 13.0 & 23.4 \\
\hline South Africa & $54.2 \%$ & $4.5 \%$ & 51770560 & 1.6 & 3.0 \\
\hline
\end{tabular}

The public higher education system in South Africa has evidently responded to the imperative for growth. Both doctoral enrolments and graduations increased significantly between 1996 and 2012/13 and at higher rates than any other degree level. The resultant growth in doctoral enrolments and graduations is the result of a variety of demand-side factors (new demands from the labour market; the demand created by the increase in students from other African countries who choose South Africa as a destination for postgraduate study), as well as supply-side factors (new master's and PhD programme offerings, increased supervisory capacity at most universities, increased funding for doctoral studies, as well as the effect of the new incentive and reward strategies of universities).

There has also been considerable progress towards achieving government expectations of increased enrolments in science, engineering and technology and business, economics and management, to the extent that science, engineering and technology candidates now constitute $51 \%$ of all doctoral enrolments. Enrolments and graduates in these fields expanded at higher average annual growth rates than in the fields of education and in humanities and social sciences.

Despite the generally positive picture that we have presented on trends in growth, the question remains whether even higher growth rates could have been achieved. Our focus thus far has been on national policy imperatives (and targets) and the response 
to these (and other demand factors) by the universities. But we should not lose sight of two other major actors: the doctoral student and the doctoral supervisor.

As far as the doctoral student is concerned we will present evidence in the following sections that points to some of the socio-economic realities that currently constrain further growth in the postgraduate pipeline. We will show how the lack of financing for full-time doctoral studies has arguably become the single biggest constraint to increasing the progression, retention and completion rates of all students, but black students in particular. We will argue (within the context of a discussion about efficiency gains) that any expectation of substantial growth must be tempered by these constraints.

Where the doctoral supervisor is concerned, we will devote a separate discussion to the realities faced by many supervisors in the country in our discussion on quality. We will show - based on a survey of experienced supervisors - that there is an increasing burden (even stress) on doctoral supervisors that acts both as a barrier to further growth (the top supervisors are already supervising too many students) as well as a serious challenge to maintain current standards of quality (increasing numbers of supervisors are taking on students outside their main area of expertise and are expected to do more remedial and support work in ensuring that a quality doctoral thesis is produced).

In summary, it is our considered view that universities have responded admirably to the demands and imperatives to grow doctoral production. This growth has exceeded the growth for any other postgraduate degree and has also slowly shifted to those fields that are aligned with national science policy goals. We will also see that this growth has occurred alongside a significant transformation in student demographics.

\section{THE DEMAND FOR EFFICIENCY}

The second discourse on doctoral production relates to the imperative of efficiency. Not surprisingly, the government wants higher graduate returns on its subsidy investments in doctoral enrolments (as in other spheres of education). In debates around efficiency, high dropout and low completion rates are regarded as major indicators of inefficiency in the production of doctoral graduates. This is consistent with the macro-economic policy, Growth, Employment and Redistribution (GEAR), which was adopted in 1996 and ostensibly aimed at growth, employment and redistribution after a massive outflow of capital. GEAR's main effect was tighter fiscal policy measures that were brought about by a cut in government expenditure and attempts at a more cost-effective civil service (Knight 2001). 


\section{PART ONE • FROM THE GLOBAL TO THE LOCAL}

This situation led to the development of efficiency indicators and targets in the 2001 National Plan for Higher Education (Ministry of Education 2001). However, targets set in the National Plan were unrealistically high: $75 \%$ of all students entering doctoral programmes in universities were expected to graduate (Ministry of Education 2001). When empirical data gathered through the Higher Education Management Information System began to show that only around 50\% of national cohorts entering doctoral programmes would eventually graduate, the target was modified to $65 \%$. This reduced target has been used for national enrolment-planning exercises in recent years, but has also proven to be unattainable.

Our analysis of efficiency in doctoral production employed four measures:

- The ratio of graduations to enrolments;

- Cohort analyses of graduating students;

- Progression and completion rates of doctoral students; and

- The ratio of PhD students to academic staff with doctorates.

\section{The ratio of graduations to enrolments}

The first measure is straightforward - even if regarded by some as a rather 'rough' proxy of efficiency. This measure simply compares the ratio of graduations to enrolments in a specific year. The data show that South African universities displayed a marginal improvement in efficiency, with an average annual increase in graduates of $6.5 \%$ compared to $6.4 \%$ in enrolments between 1996 and 2012 (Figure 4.5).

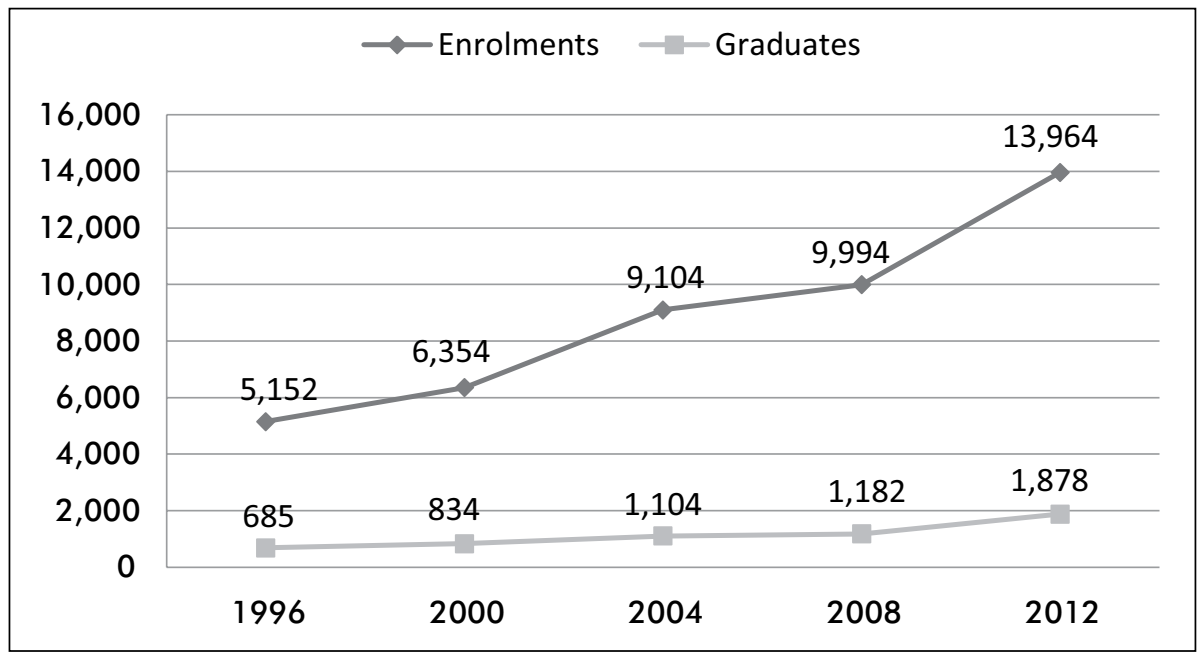

FIGURE 4.5 Comparison of doctoral enrolments and graduates (1996-2012) 


\section{Cohort analyses of graduating students}

The second measure comprises an analysis of different age cohorts and tracking them over an extended period of time. We analysed three cohorts (the 2003, 2004 and 2005 cohorts) and tracked them for different periods. The results showed that the average graduation rate after five years was $35 \%$ which then increased to $42 \%$ after seven years. The 2006 cohort had a $43 \%$ completion rate after six years, while the 2007 cohort showed a $45 \%$ completion rate after the same period of time. On average, we found that $46 \%$ of all doctoral students would typically complete their studies after seven years of study. We also calculated the average time to degree for a doctoral student (across all scientific disciplines); it came to 4.8 years. It is worth reminding ourselves that about two thirds of South African doctoral students study part-time, that is they study while working. In comparing these results with international data, we found that an average completion rate of $46 \%$ and average TTD (time to degree) of 4.8 years in fact compares favourably with trends in countries such as Canada, Australia and the USA.

\section{Progression and completion rates of doctoral students}

The third measure of efficiency that was employed can be defined as a 'progression and completion' measure as it looked at the pipeline of production of doctoral students. In this analysis we tracked individual postgraduate students starting with the master's graduates of 2001.' (See Figure 4.6)

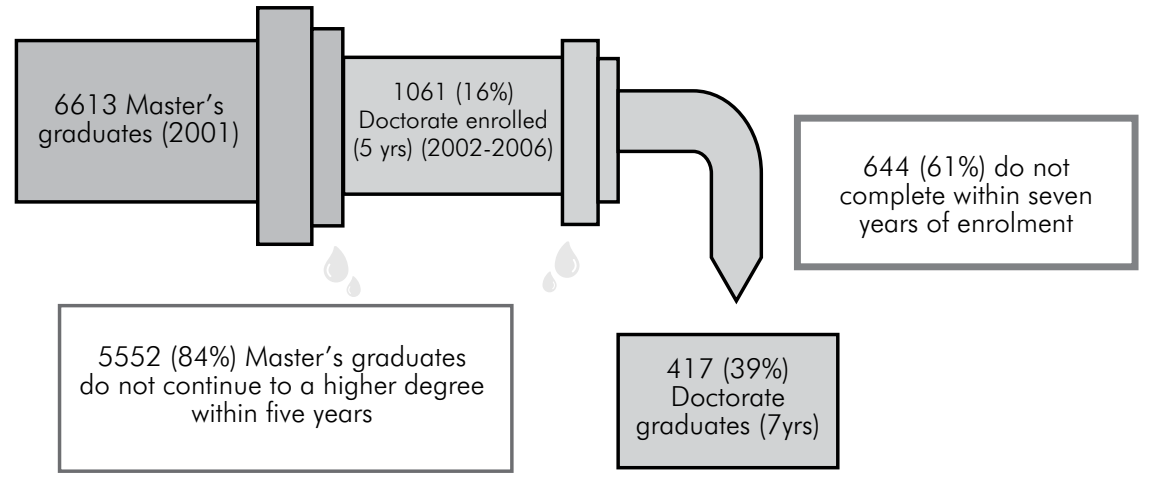

FIGURE 4.6 Progression and completion for master's to doctorate

The analysis presented in Figure 4.6 shows that of an initial sample of 6613 master's graduates in 2001, only $16 \%$ would enrol for doctoral studies in the following five

1 The full report is on the pipeline of doctoral production in SA available at: http://www0.sun. ac.za/crest 
years. Of these 1061, only 417 (or 39\%) would eventually graduate (after another seven years). This, and similar analyses for other samples, shows the huge attrition in the doctoral pipeline. These progression trends reveal a very worrying picture of regular interruptions of studies. The typical study trajectory from a completed bachelor's to a completed doctoral degree can be anywhere between 12 (minimum period) and 25 years (average maximum). But the problem is not merely a leaking pipeline at every level of the system; the pipeline is also progressively shrinking at what may be regarded as an alarming rate!

In an attempt to gain a more qualitative understanding of the factors that affect progression and completion rates, the Centre for Research on Evaluation, Science and Technology (CREST (2014)) conducted a national survey of postgraduate students enrolled at South African universities during 2014. The total number of completed questionnaires was 5 700. In the following paragraphs the salient findings of this survey are presented.

Low progression and retention rates are mainly due to the part-time nature of studies (which is related to the lack of funding for full-time studies).

All the evidence generated by the survey points to the fact that the most dominant factor that explains low progression and retention rates is that between 60 and $70 \%$ of SA students study part-time (study while they work). This conclusion is supported by a number of specific findings from the survey:

- The most commonly cited reason for students interrupting their studies was that of employment conditions or work obligations. This reflects the fact that the majority of students (between 60 and 70\%) work while studying.

- The progression rates for younger students (both at the honours and master's levels) are higher than for older age cohorts, who are more likely to be working while studying.

- Additionally, among the top three reasons given for considering dropping out, across all three levels of study, are challenges to find sufficient time for studies, for example, the challenge of balancing work with studies. This is particularly pertinent to master's and doctoral students, as well as students older than 30 years.

- Doctoral students who study full-time complete their studies on average in half of the time (just over three years) that it takes part-time students to complete their studies (just over five years).

Students in the natural sciences (where larger proportions study full-time) have significantly higher progression and completion rates. The effect of part-time studies 
is also evident when we compare progression and completion rates across different scientific fields. Again, the evidence for this conclusion is provided from a number of specific survey findings:

- The progression and completion rates for bachelor's to honours students are better for students enrolled in the natural sciences and business, economic and management sciences than in other fields of study. This is also true for honours and master's students, as students enrolled in the natural sciences' progression and completion rates are almost 15\% higher than for the humanities and social sciences.

- The natural sciences consistently record better progression and completion rates across all three levels of study. Students enrolled in the social sciences and humanities emphasised the challenge of coping with study demands and finding sufficient time for studies, whereas this was not the case with students enrolled in the natural sciences.

- A greater percentage of the latter (together with students in engineering and the health sciences) also indicated that they intended to enrol immediately for another university degree after completing their current degree, whereas this intention was not as prominent among students in the social sciences and humanities.

- When looking at the average age of South African honours students in 2013, students in the natural sciences, engineering and business, economics and management sciences were on average younger than students enrolled in other sciences. The average age of honours students in education was significantly higher.

These age differences, as well as differences in progression and completion rates also correlate clearly with the fact that larger proportions of students in the social sciences and humanities are enrolled part-time, and therefore take longer to complete, are older and often struggle with the demands of their studies.

\section{The ratio of PhD students to academic staff with doctorates}

Ourfinal measure of efficiency shifts the attention to the doctoral supervisor and analyses the ratio of doctoral graduates to the number of academic staff with doctorates. Using this measure the data show that there has been an increase in the overall efficiency in the system in the recent past (Table 4.2).

Over the recent period (2011-2013) the national ratio of doctoral graduates to staff holding doctorates at all South African universities increased from 0.25 (2011) to 0.28 (2013). This means that - on average - every staff member at a South African 
university with a PhD 'delivers' a PhD in about three and a half years. But again we see that there are huge institutional differences. At the best performing ('most efficient') universities in 2013 (Stellenbosch University, the University of the Western Cape, the University of Pretoria, Rhodes, and the University of the Witwatersrand) each staff member with a doctorate produced a PhD in less than three years.

TABLE 4.2 Number of PhDs and staff with doctorates by university (2011-2013)

\begin{tabular}{|c|c|c|c|c|c|c|c|c|c|}
\hline & \multicolumn{3}{|c|}{2011} & \multicolumn{3}{|c|}{2012} & \multicolumn{3}{|c|}{2013} \\
\hline University & $\begin{array}{l}\text { Staff } \\
\mathrm{PhD}\end{array}$ & $\begin{array}{l}\text { PhD } \\
\text { Grad }\end{array}$ & $\begin{array}{l}\text { Grad: } \\
\text { Staff }\end{array}$ & $\begin{array}{l}\text { Staff } \\
\mathrm{PhD}\end{array}$ & $\begin{array}{l}\text { PhD } \\
\text { Grad }\end{array}$ & $\begin{array}{l}\text { Grad: } \\
\text { Staff }\end{array}$ & $\begin{array}{l}\text { Staff } \\
\mathrm{PhD}\end{array}$ & $\begin{array}{l}\text { PhD } \\
\text { Grad }\end{array}$ & $\begin{array}{l}\text { Grad: } \\
\text { Staff }\end{array}$ \\
\hline SU & 521 & 150 & 0.29 & 516 & 240 & 0.47 & 614 & 225 & 0.37 \\
\hline UP & 616 & 206 & 0.33 & 623 & 200 & 0.32 & 658 & 242 & 0.37 \\
\hline UWC & 283 & 80 & 0.28 & 290 & 75 & 0.26 & 301 & 111 & 0.37 \\
\hline$R U$ & 174 & 57 & 0.33 & 171 & 67 & 0.39 & 198 & 70 & 0.35 \\
\hline WITS & 560 & 169 & 0.30 & 595 & 150 & 0.25 & 639 & 221 & 0.35 \\
\hline UNISA & 455 & 93 & 0.20 & 611 & 152 & 0.25 & 625 & 201 & 0.32 \\
\hline UKZN & 606 & 154 & 0.25 & 663 & 177 & 0.27 & 688 & 207 & 0.30 \\
\hline NMMU & 212 & 59 & 0.28 & 226 & 86 & 0.38 & 245 & 74 & 0.30 \\
\hline UCT & 667 & 163 & 0.24 & 699 & 198 & 0.28 & 725 & 205 & 0.28 \\
\hline NWU & 582 & 115 & 0.20 & 624 & 154 & 0.25 & 634 & 168 & 0.26 \\
\hline CPUT & 91 & 13 & 0.14 & 106 & 24 & 0.23 & 113 & 28 & 0.25 \\
\hline UFH & 102 & 44 & 0.43 & 119 & 43 & 0.36 & 124 & 30 & 0.24 \\
\hline UFS & 349 & 107 & 0.31 & 374 & 94 & 0.25 & 393 & 91 & 0.23 \\
\hline TUT & 136 & 28 & 0.21 & 144 & 44 & 0.31 & 150 & 32 & 0.21 \\
\hline DUT & 73 & 14 & 0.19 & 88 & 6 & 0.07 & 97 & 18 & 0.19 \\
\hline CUT & 60 & 5 & 0.08 & 60 & 5 & 0.08 & 71 & 12 & 0.17 \\
\hline UJ & 287 & 68 & 0.24 & 294 & 109 & 0.37 & 451 & 78 & 0.17 \\
\hline UZ & 82 & 19 & 0.23 & 79 & 28 & 0.35 & 92 & 14 & 0.15 \\
\hline UL & 147 & 17 & 0.12 & 132 & 17 & 0.13 & 139 & 14 & 0.10 \\
\hline VUT & 44 & 2 & 0.05 & 41 & 2 & 0.05 & 42 & 4 & 0.10 \\
\hline WSU & 73 & 4 & 0.05 & 69 & 3 & 0.04 & 76 & 3 & 0.04 \\
\hline UV & 103 & 9 & 0.09 & 103 & 4 & 0.04 & 116 & 3 & 0.03 \\
\hline MUT & 16 & 0 & 0.00 & 16 & 0 & 0.00 & 18 & 0 & 0.00 \\
\hline National & 6239 & 1576 & 0.25 & 6643 & 1878 & 0.28 & 7209 & 2051 & 0.28 \\
\hline
\end{tabular}

(Source: DHET 2013a)

In summary: Our analyses of the efficiency of doctoral education have produced a mixed picture. The analysis of the doctoral pipeline revealed low progression rates. For example, only $24 \%$ of bachelor's students enrolled for an honours degree, just over $20 \%$ of honours graduates enrolled for a master's and only $16 \%$ of master's 
graduates enrolled for doctoral study within five years. Consequently, the pipeline is not only a leaky one, but also very long. From a systems perspective this is indicative of a very inefficient system. We lose too many students between the bachelor's and doctoral level and those who do manage to afford to stay in the system take too long to progress from bachelor's to doctoral studies. We have argued that the major cause of this state of affairs is the lack of sufficient funding (especially for black students) to study full-time and hence to complete their studies within much shorter periods of time.

But there is also another side to the efficiency argument. Despite the lack of sufficient funding for doctoral studies, regular interruptions of studies for work- and employment-related reasons and hence an older-than-average doctoral cohort (compared to the age of students completing in Europe and North America), completion rates compare favourably with international benchmarks. Despite high teaching loads and the increasing 'burden of supervision', academic staff at the top South African universities have increased their PhD output in recent years. All of this evidence suggests that South African universities and supervisors are quite efficient in the production of graduates who are in the system. Thus, university support for and supervision of doctoral students is not the major problem in the system. These structures and mechanisms are in themselves quite efficient; this is particularly evident when we focus on the throughput and completion rates of the top research universities.

\section{THE IMPERATIVE FOR TRANSFORMATION}

The third policy discourse concerns the imperative of transformation. There have been many reviews of transformation, or the lack thereof, but one of the most comprehensive theoretical and policy reviews was by Badat (2004). Starting with the National Commission on Higher Education in 2000, Badat listed the main areas of transformation as system and structures, equity, quality and responsiveness. He subsequently reduced his focus to two key areas, namely institutional restructuring and human resources.

When transformation is understood solely within a discourse on equity and redress, and the focus is on changing the demographics of race and gender, the evidence shows significant transformation. Whether one looks at absolute increases in the number of black and female students or annual growth rates, the results are the same. 
During the period 1996 to 2012 , the relative proportion of African (black) ${ }^{2}$ doctoral graduates increased from $8 \%$ to $44 \%$ while the proportion of whites declined from $86 \%$ to $43 \%$. (See Figure 4.7.)

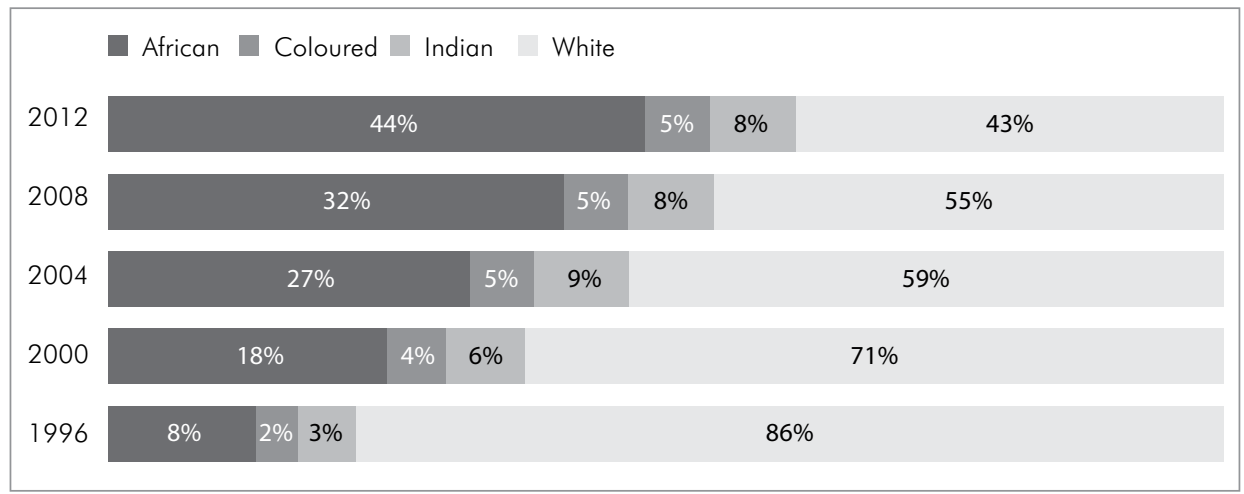

FIGURE 4.7 Percentage of doctoral graduates by race (1996-2012) (Sources: DoE 1999; DHET 2013a)

As far as enrolments are concerned, African black doctoral students increased their share from $13 \%$ in 1996 to $32 \%$ in 2004 and to $48 \%$ in 2012. Similarly, the share of coloured doctoral enrolments increased from $4 \%$ to $6 \%$, and the share of Indian doctoral students from $5 \%$ to $8 \%$. By contrast, the proportion of white doctoral enrolments dropped from $78 \%$ in 1996 to $38 \%$ in 2012 . The same trends apply to doctoral graduations where the proportion of African doctoral graduates increased from $8 \%$ to $44 \%$, while the proportion of whites declined from $86 \%$ to $43 \%$ between 1996 and 2012. Similar shifts were recorded as far as gender is concerned. By $2012,42 \%$ of all doctoral graduates were female, compared to $35 \%$ in 1996.

However, the discussion about transformation in terms of a racial definition becomes more problematic when we introduce 'nationality' into the equation. As discussed above, the increases in African (black) male and female students (enrolments and graduates) in particular were the result of the influx of students from the rest of Africa. The reality is that the South African doctorate would not have changed (transformed) to the extent that it has without the injection of large numbers of students from the rest of the continent. And, of course, it raises the question whether this constitutes 'transformation' as it was (originally) intended by policy-makers and government. Or

2 In this section we will - for the sake of clarity - refer to black (African) students when referring to South African-African students (if the context is not clear). When we refer to students from other African countries, we will refer to African (rest of Africa) students. As we explain in the text, this clarification is necessary as we use the term 'African' both in a demographic and a geographic sense. 
are we simply confusing two very different notions of 'African': a 'racial' definition with a 'geographical' one?

The African doctoral students in South Africa come from the continent as a whole and not just South Africa. Our focus in this section is on African students only. In 2000 the number of South African-African (black) enrolments (990) was almost double that of the rest of Africa (526). But by 2012 there were 750 more enrolments and 171 more graduates from the rest of Africa than there were from South AfricanAfricans. A notable change happened in the period between 2004 and 2008: the South African-African enrolments increased by 258 (15\%) and the rest-of-Africa enrolments by 844 (71\%). These trends are quite clearly illustrated in Figures 4.8 and 4.9 that present the changes in enrolment and graduation numbers of African doctoral students since 2000 .

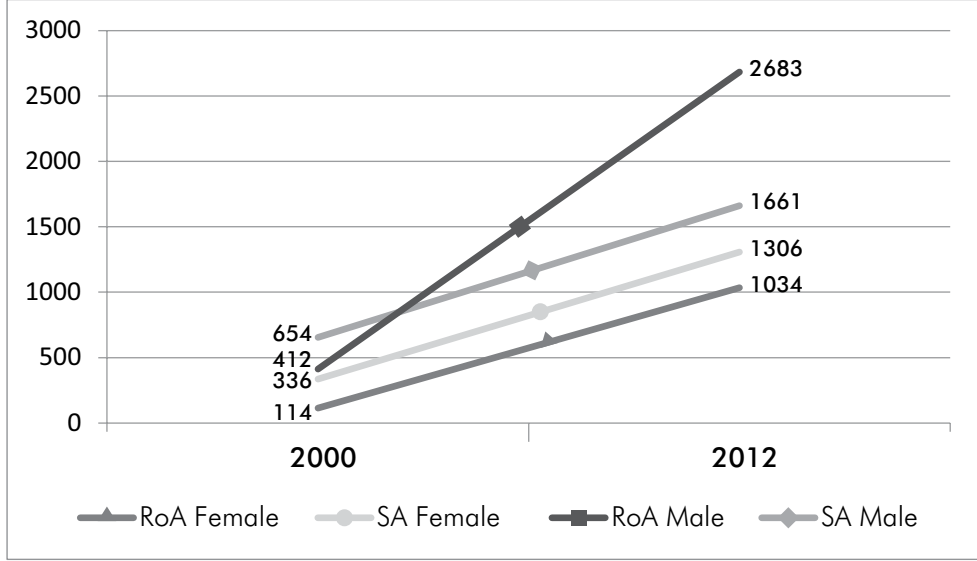

FIGURE 4.8 African doctoral enrolments by nationality and gender (2000 and 2012)

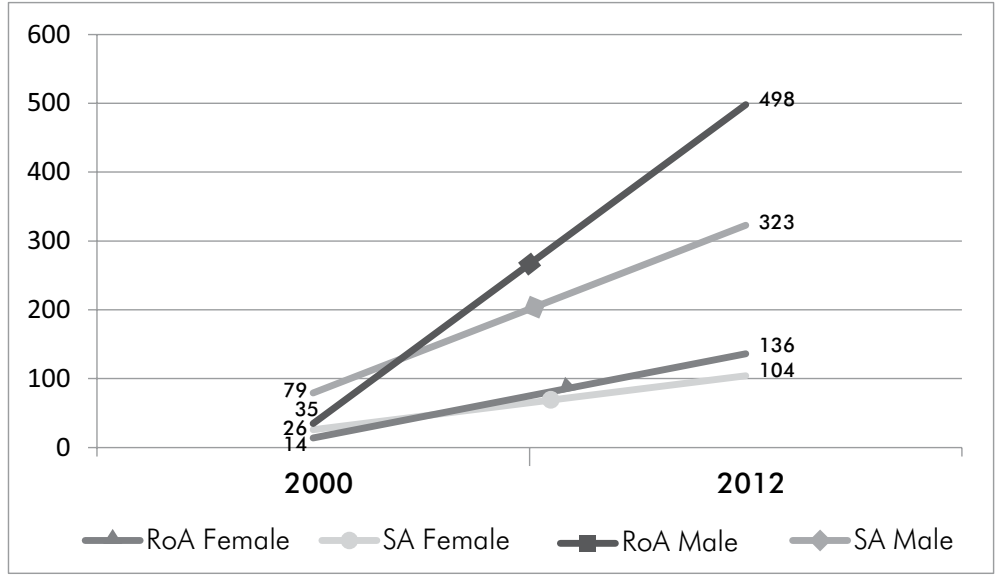

FIGURE 4.9 African doctoral graduates by nationality and gender (2000 and 2012) 
A comparison of the growth rates for the different subgroups shows that doctoral enrolments of students from the rest of Africa grew at $17.7 \%$ and graduates at $21.3 \%$. These rates are more than double the rate for South African students for which the average annual growth rates were $9.6 \%$ for enrolments and $9.9 \%$ for graduations respectively.

Do we count African students from the rest of Africa when we ask questions about transformation? Or should we limit our analyses to South African doctoral students only (irrespective of race) when assessing the pace of transformation? A similar question could be raised about gender. Table 4.3 shows that the growth rates of African female students from other African countries also outstripped the growth rates of African female students from South Africa (as far as both enrolments and graduations are concerned).

TABLE 4.3 African doctoral enrolments and graduates from South Africa and the rest of Africa by gender (2000-2012)

\begin{tabular}{|c|c|c|c|c|c|c|c|c|c|}
\hline \multirow[t]{2}{*}{ Nationality } & \multicolumn{3}{|c|}{2000} & \multicolumn{3}{|c|}{2012} & \multicolumn{3}{|c|}{$\begin{array}{l}\text { Average annual growth } \\
\text { rate 2000-2012 }\end{array}$} \\
\hline & Female & Male & Total & Female & Male & Total & Female & Male & Total \\
\hline \multicolumn{10}{|l|}{ Enrolments } \\
\hline South Africa & 336 & 654 & 990 & 1306 & 1661 & 2967 & $12.0 \%$ & $8.1 \%$ & $9.6 \%$ \\
\hline Rest of Africa & 114 & 412 & 526 & 1034 & 2683 & 3717 & $20.2 \%$ & $16.9 \%$ & $17.7 \%$ \\
\hline Total & 450 & 1066 & 1516 & 2340 & 4344 & 6684 & $14.7 \%$ & $12.4 \%$ & $13.2 \%$ \\
\hline \multicolumn{10}{|l|}{ Graduates } \\
\hline South Africa & 26 & 79 & 105 & 104 & 219 & 323 & $12.2 \%$ & $8.9 \%$ & $9.8 \%$ \\
\hline Rest of Africa & 14 & 35 & 49 & 136 & 362 & 498 & $20.9 \%$ & $21.5 \%$ & $21.3 \%$ \\
\hline Total & 40 & 114 & 154 & 240 & 581 & 821 & $16.1 \%$ & $14.5 \%$ & $15.0 \%$ \\
\hline
\end{tabular}

One way to clarify the debate on transformation is to shift the focus to participation rates as opposed to growth rates. And then the transformation question needs to be reformulated: Are more South African-African (black) students participating in doctoral studies today than 13 years ago? The evidence presented shows that the rate for South African-African students (male and female) increased from 0.84 to 3.61 students per 100000 of the age-relevant population group. This constitutes a fourfold increase in participation rates. But this substantial increase must be seen in relation to the same statistics for white students: whereas the share of white enrolments declined over the same period, their participation rates increased from 45 to 63 per 100000 of the age-relevant population. In fact, the participation rate for white students compares well with populations of developed countries. 
The rate of participation must be assessed in terms of the size of the overall system and in relation to population changes. South Africa's overall higher education participation rate is low - around $20 \%$. With regard to population growth, the white population for enrolments in the 20-to-24-year age cohort declined from 349102 in 1996 to 316000 in 2012 - an overall decline of 9\%. In contrast, the African black population for enrolments in this age cohort increased by 974918 (31\%), from 3153082 to 4128000 . All of this means that for (South African) African students to equal the participation rates of their white counterparts, a total of 5688 African doctoral graduates would have been required in 2012, which is 17.5 times more than the 325 African doctorate graduates for that year!

TABLE 4.4 African and white doctoral graduates 1996 and 2012 compared to 30-to-49year-old age cohort

\begin{tabular}{|c|c|c|c|c|c|c|}
\hline Year & $\begin{array}{l}\text { African } \\
\text { females }\end{array}$ & $\begin{array}{l}\text { African } \\
\text { males }\end{array}$ & Total & $\begin{array}{l}\text { White } \\
\text { females }\end{array}$ & $\begin{array}{l}\text { White } \\
\text { males }\end{array}$ & Total \\
\hline 1996 South African graduates & 10 & 48 & 58 & 219 & 368 & 587 \\
\hline 2012 South African graduates & 106 & 219 & 325 & 449 & 367 & 816 \\
\hline 2012 Rest of Africa & 134 & 362 & 496 & & & \\
\hline $\begin{array}{l}\text { 30-to-49-year-old population - } \\
1996 \text { (x 1000) }\end{array}$ & 3333 & 3606 & 6939 & 634 & 658 & 1292 \\
\hline $\begin{array}{l}\text { 30-to-49-year-old population - } \\
2012 \text { ( x 1000) }\end{array}$ & 4470 & 4545 & 9015 & 449 & 456 & 905 \\
\hline $\begin{array}{l}\% \text { increase for South African } \\
\text { graduates - } 2012 \text { vs. } 1996\end{array}$ & $960 \%$ & $356 \%$ & $460 \%$ & $105 \%$ & $0 \%$ & $39 \%$ \\
\hline $\begin{array}{l}\% \text { change in the } 30 \text {-to- } 49 \text {-year age } \\
\text { cohort }\end{array}$ & $34 \%$ & $26 \%$ & $30 \%$ & $-29 \%$ & $-31 \%$ & $-30 \%$ \\
\hline $\begin{array}{l}1996 \text { graduates per } 100000 \\
\text { of the } 30 \text {-to- } 49 \text {-year-old } \\
\text { population cohort }\end{array}$ & 0.30 & 1.33 & 0.84 & 34.54 & 55.93 & 45.43 \\
\hline $\begin{array}{l}2012 \text { graduates per } 100000 \\
\text { of the } 30 \text {-to-49-year-old } \\
\text { population cohort }\end{array}$ & 2.37 & 4.82 & 3.61 & 100.00 & 80.48 & 63.16 \\
\hline
\end{tabular}

(Sources: DHET 2013a; Statistics South Africa 2004; Statistics South Africa 2013).

\section{THE IMPERATIVE OF QUALITY}

The fourth discourse concerns the quality of doctoral production. Although the 1996 National Commission on Higher Education report and the 1997 Education White Paper (DoE 1997) stated that quality throughout the system was important, neither document discussed methods by which the quality of doctoral programmes could be assessed (NCHE 1996; DoE 1997). An indirect start to the quality debate was the 2000 Council on Higher Education report (CHE 2000) on the size and shape of 
the higher education system. The CHE report proposed a differentiation framework that placed institutions into rigid categories. By implication this was a quality control mechanism, since it was intended that these categories would determine whether or not an institution could offer doctoral programmes. Despite the requirement for ministerial approval for programme and qualifications mixes (PQMs), very few of the doctoral programmes offered by South African higher education institutions have thus far undergone detailed quality reviews by the $\mathrm{CHE}$. Instead, the Higher Education Quality Committee (HEQC) accreditation model (HEQC 2004) located the responsibility for higher education programme quality with the institutions themselves and proposed that institutions should maintain in-house quality assurance mechanisms. The HEQC would review the effectiveness of associated quality assurance mechanisms within the universities and validate the institutions' own monitoring information in this regard.

'Quality' of doctoral education is an elusive and complex construct. In order to get closer to an operational definition, it is necessary that we examine its constituent dimensions. Cloete, Mouton and Sheppard (2015) distinguished between seven dimensions of quality:

- The quality of the doctoral candidate (at entry level)

- The quality of the doctoral programme

- The quality of the doctoral supervisor

- The quality of the supervisory process

- The quality of the doctoral graduate (at exit)

- The quality of the doctoral thesis

- The quality of any journal paper or presentation emanating from the doctoral thesis

Our focus in this chapter is on three of these dimensions: the level of preparedness of doctoral candidates, the quality of the supervisory process, and the quality of the doctoral graduate.

\section{Level of preparedness of the doctoral candidate}

In our discussion on efficiency above we reported on the typical trajectories of postgraduate students in South Africa. Given that between $60 \%$ and $70 \%$ of all honours, master's and doctoral students in South Africa study part-time (they work while they study), we highlighted the fact that large proportions of students invariably interrupt their studies. We showed that the typical study trajectory from a completed 
bachelor's to a completed doctoral degree can be anywhere between 12 (minimum period) and 25 years (average maximum), which explains why the average age of doctoral graduates in 2013 was 41 and the average time to completion of doctoral degree remains close to five years!

In the CREST study of doctoral enrolments (CREST 2014) it was found that the most commonly cited reason for students interrupting their studies was that of employment conditions or work obligations followed by financial reasons. It was also found that the progression rates for younger students (both at the honours and the master's levels) were higher than for older age cohorts, who are more likely to be working while studying. And finally, among the top three reasons given for considering dropping out, across all three levels of study, were challenges to find sufficient time for studies, for example, the challenge of balancing work with studies. This is particularly pertinent to master's and doctoral students, as well as students older than 30 years.

All of this adds up to a picture where large proportions of South African doctoral students - by the time that they enrol for their doctoral degree - would have typically interrupted their study career a number of times. Instead of an ideal trajectory where the student progresses quite quickly from undergraduate to lower and higher postgraduate levels, the typical South African doctoral student (with the possible exceptions of students in some of the natural sciences) enrols for doctoral studies after a number of gaps and interruptions between honours and master's and between master's and doctorate.

Evidence from workshops on doctoral supervision at many South African universities shows that supervisors are not only finding the increased numbers of students to supervise challenging, but - even more importantly - also the reality that a large number of prospective doctoral candidates are woefully underprepared for doctoral studies. Supervisors complain that many of their doctoral students cannot write scientifically, do not know how to search the literature, lack the required quantitative and qualitative skills to do proper data analysis, and so on. In cases where doctoral students are underprepared for the specific demands of doctoral studies, the doctoral supervisor has to devote more time to guiding the student through the doctoral research process.

\section{The quality of the doctoral supervisory process}

A survey of Stellenbosch University doctoral students conducted in 2001 (Mouton \& Hunter 2001) asked doctoral graduates a number of questions about their doctoral experience. One of the sets of questions was aimed at establishing to what extent 
the students had required a little, some or a lot of guidance from their supervisors. Responses regarding supervisor guidance are reflected in Figure 4.10.

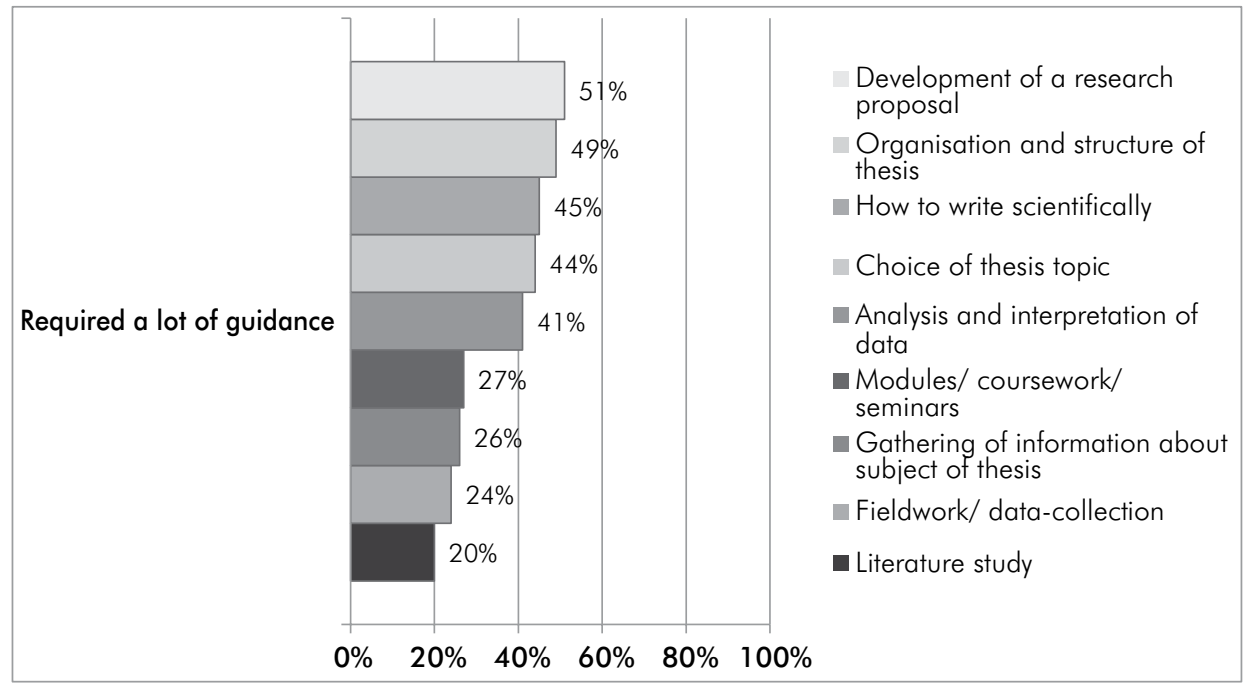

FIGURE 4.10 Responses on supervisor guidance

The results were revealing as large proportions of students said that they required a lot of guidance with regard to the development of their research proposal (51\%), the organisation of their thesis (49\%), how to write scientifically $(45 \%)$ and even in choosing their thesis topic (44\%). In an ideal world, the doctoral candidate should be reasonably well-prepared for most of these tasks. This is evidently not the case even at one of the top universities in the country.

The burden of increasingly large numbers of doctoral students to supervise will manifest itself in different ways during the supervisory process. In a more recent study of doctoral supervision in South Africa we addressed two specific questions: Firstly, what would the effect of large numbers be on the alignment between the expertise of the supervisor and the expectations and demands of the student? Secondly, what effect would the large numbers have on the time and attention that the supervisor can devote to each student?

As to the first issue, we asked supervisors whether they sometimes have to accept students who work outside their own area of expertise. This is an important issue because it is generally accepted that there is a big difference in how supervision is conducted where the supervisor is supervising students in his or her area of expertise, as opposed to areas where the supervisor would not claim any expertise. When supervising students in one's own area of expertise (areas where the supervisor has 
published, given presentations and is generally recognised as an expert by his or her peers), the supervisory process is much more straightforward. On the other hand, when one has to supervise a doctoral student in areas outside one's own expertise, the supervisor needs to put in much more effort in keeping abreast with developments and trends in that field, and also with the student as the process unfolds. These issues are directly linked to the quality of the supervision given.

Our study found - and this is clearly cause for concern - that a sizeable percentage (45\%) of all respondents indicated that they sometimes have to supervise students outside their main area of expertise. The breakdown by main scientific field (Figure 4.11) shows that this situation is slightly more common in the social sciences, humanities and arts (SSHA), and in the economic and management sciences (EMS).

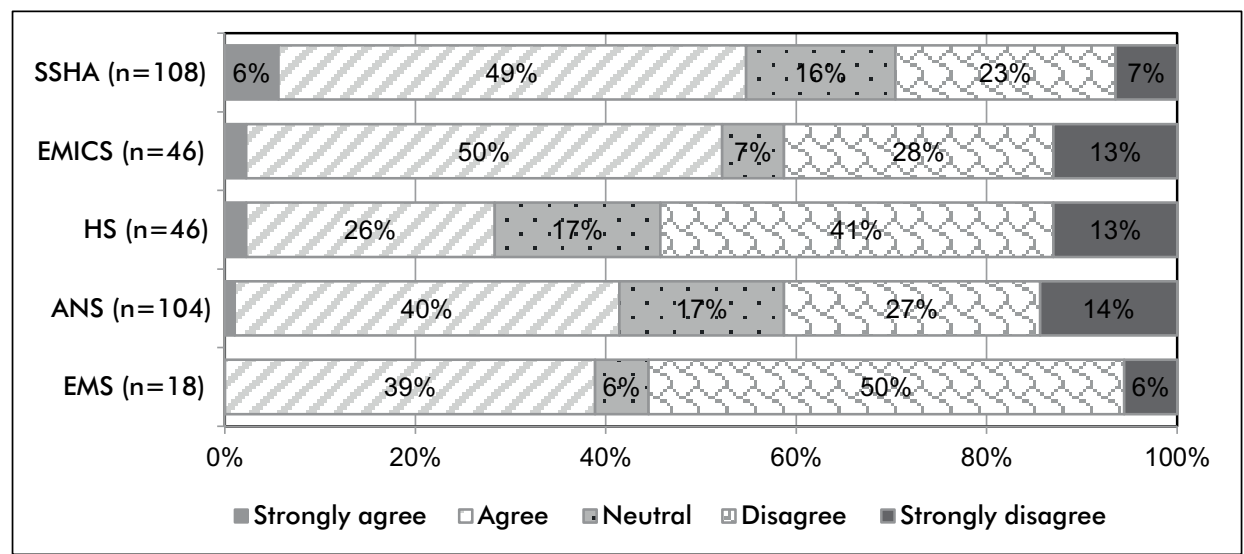

EMICS = Engineering and Mathematical Sciences

ANS = Agricultural and Natural Sciences

$H S=$ Health Sciences

EMS = Economic and Management Sciences

SSHA = Social Sciences, Humanities and Arts

FIGURE 4.11 Extent of agreement with statement: 'I sometimes have to supervise PhD work that lies outside my area of expertise', by scientific field

Our second question asked how the increasing burden of supervision affects the attention that supervisors are able to give students. The results again are interesting: significant numbers of supervisors (32\%, nearly a third of the respondents) felt that they do not give sufficient attention to their students. The disaggregation by main scientific field (Figure 4.12) shows that this situation holds for all fields, with an even larger proportion (60\%) of respondents from the engineering and mathematical sciences (EMICS) discipline agreeing with the statement (although the actual numbers are small). 


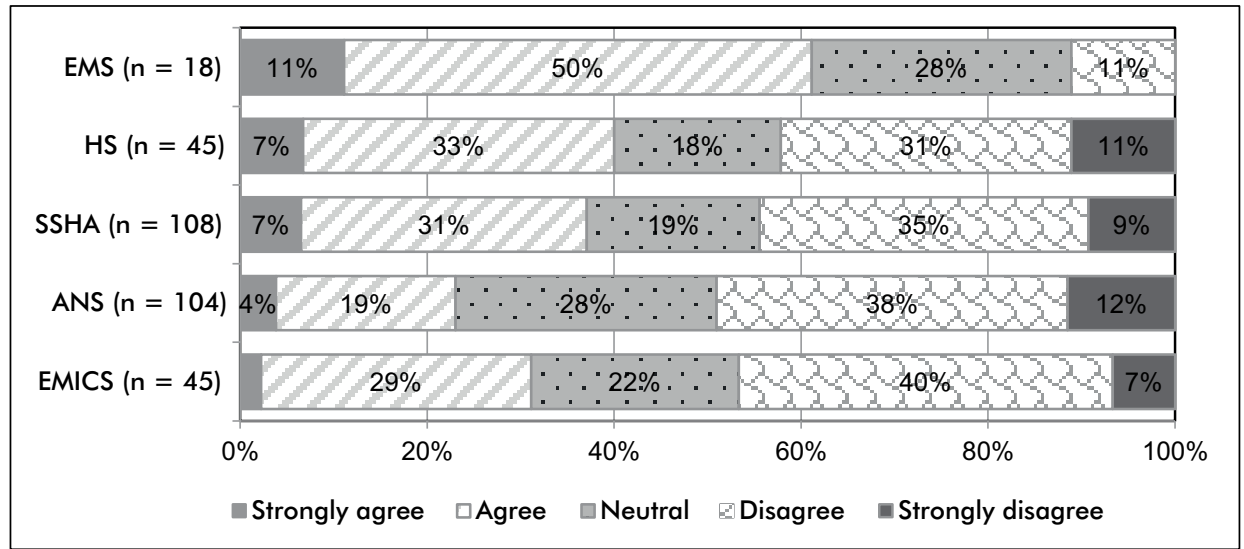

FIGURE 4.12 Extent of agreement with statement: 'I lack sufficient time to give each PhD student the attention that he or she deserves', by scientific field

In summary: Understanding how good quality supervision occurs is not straightforward. A perspective from the supervisor highlights concerns about the amount of time and attention students require, their own time and expertise in the domain of the study, and their own levels of experience. The perspective from the student is likely to be variable. Some students (who are better qualified, who are being supervised by the supervisor of their choice, who are well-supported by the university and department) are likely to report on good quality practices. On the other hand, various studies have reported on student dissatisfaction with the quality of doctoral supervision. In the absence of a comprehensive survey of doctoral experiences in South Africa (and not merely small-scale qualitative and often anecdotal studies), we would maintain that the quality of doctoral supervision is more likely to be good.

\section{Quality of the doctoral graduate}

The final 'product' of the doctoral education process is the doctoral graduate: someone who should in theory be more employable because he or she is more knowledgeable, skilled and competent in knowledge production. It has become common practice in doctoral destination and tracer studies (and also employer studies) to establish what the level of employability of doctoral graduates is (the quantitative question) as well as a more qualitative question about the 'fit' between the doctoral graduates and the demands of a specific employment. The evidence for this section is sourced from a study conducted by CREST in 2010 (Mouton, Boshoff \& Ritter 2010) under commission from ASSAf. 


\section{Degree of employability}

ASSAf commissioned CREST at Stellenbosch University to conduct a tracer survey of humanities graduates from South African universities. Eighteen of the 23 universities in the country participated in the survey. A total realised sample of 12064 graduates had completed the Web-based questionnaire by the close of the survey, making this one of the biggest graduate tracer studies ever conducted in South Africa. A total of 3617 graduates from the social sciences, humanities and arts (SSHA) completed the survey; 2936 graduates from the economic and management sciences (EMS) and 5488 graduates in the agricultural, natural, engineering and health sciences (NEHS). A small number (23) of students did not indicate their field of study.

A main finding of the study was that the majority of graduates from all fields of science obtained their first job in less than one month after graduation. In all three broad domains within SSHA the tendency is for graduates to find work within a period of six months after graduation, with the majority who find work in less than one month. Moreover, especially in the social Sciences there appears to be a shift from finding work in less than one month after graduation to between one and six months after graduation. This is evident in the fact that $79 \%$ and $18 \%$ of graduates from the most historical year-period (before 1980) reported that they had found work in less than one month and between one and six months, respectively, compared with $54 \%$ and $36 \%$ of respondents in the most recent graduate period (2000-2010).

\section{Preparation for employment}

One of the questions that were put to respondents that is particularly relevant to our discussion is whether they felt that their doctoral degree had prepared them for employment. Figure 4.13 shows that the majority of respondents across all fields felt that their doctoral qualification prepared them well or very well for employment.

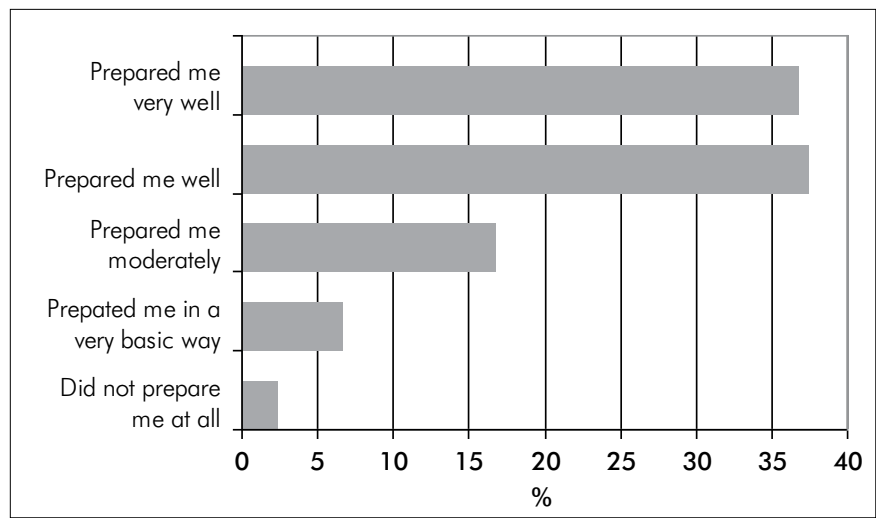

FIGURE 4.13 Has the doctoral degree prepared you well for employment or not 
$\mathrm{PhD}$ graduates that indicated that their doctoral degree did indeed prepare them for employment were also asked to explain in what way the qualification prepared them for employment. The top 10 reasons mentioned are displayed in Figure 4.14 below. The ability to design and manage a research project was considered the most important preparation for employment. This is closely linked to the ability to think and work independently. Having specialised subject knowledge also opened and eased the entry into employment for a number of PhD graduates. It would also seem that a doctoral qualification provided confidence and acceptance into the scientific world for some of the respondents.

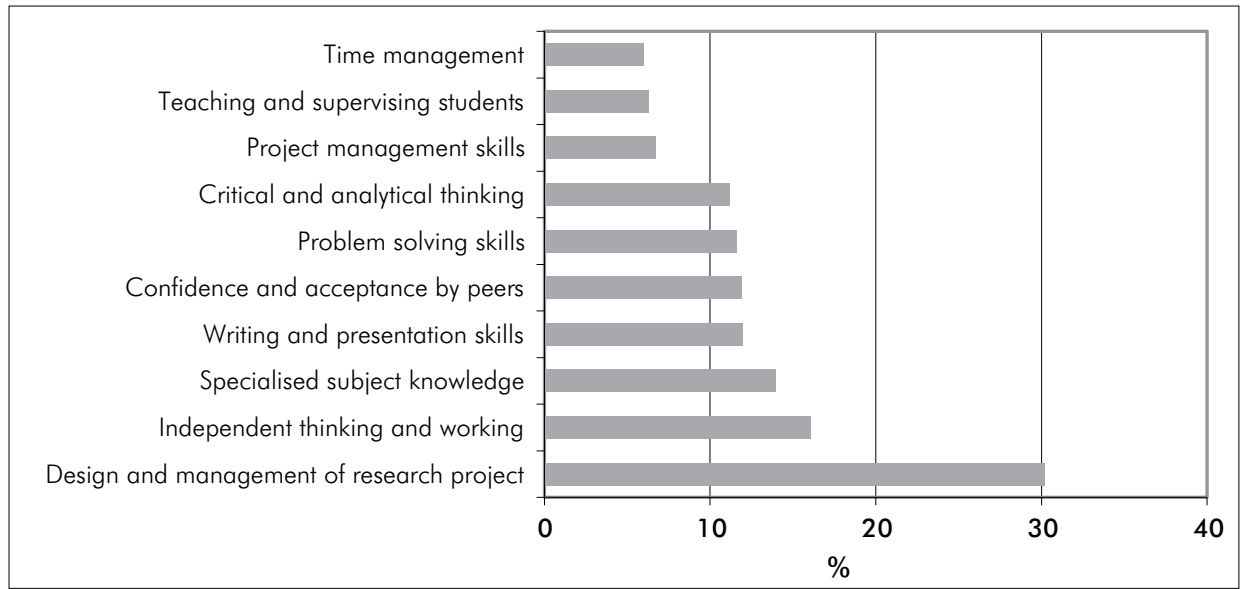

FIGURE 4.14 How doctoral studies prepared them for the world of work $(n=285$ )

In summary: Although South African higher education does not have an abundance of tracer of destination studies, the few studies (with reasonable sample sizes) consistently present the same results: vast majorities of South African graduates and especially doctoral graduates who do not have employment on completion of their studies find employment relatively quickly. There is nearly no unemployment of doctoral graduates to speak of. Studies of doctoral graduates and employers also concur that there is acceptable alignment between the demands of the workplace and the skills and competencies of the graduates. Although these are indirect measures, the picture that emerges from all of these studies (Botha 2015) provides positive evidence in the quality of the doctoral degree and candidate in the country. In conclusion: Our overall assessment, then, is that the quality of doctoral education in South Africa is generally good. However, at the same time we need to caution against any complacency as there are already isolated indications of strains on the system, which may in the long run compromise quality. The imperative to improve quality is and should be an essential goal of any system of doctoral education. 


\section{IMPERATIVES AS SOCIAL CONSTRUCTS}

We began this chapter with a statement of our central thesis, namely that four imperatives intersect in current debates on the production of PhDs in South Africa. We argued that these imperatives are embedded in various policy and strategy documents produced by the South African government over the past two decades. We do not assume that these 'imperatives' are necessarily independent or objective forces that generated specific actions in any direct and linear fashion. The 'system' in which they operate - the doctoral education system - is a complex system in which unilineal causality is the exception rather than the rule.

We have selected and interpreted these four imperatives as influential discourses that have shaped and influenced doctoral production in the recent past (and continue to do so). Although we would argue that these four discourses are the most dominant as far as the doctorate is concerned, there are conceivably other ways to interpret these imperatives. Also, it is not inconceivable that one could identify other imperatives that have also shaped doctoral production in the country. Indeed, we argue that the demand for transformation has been confounded in recent years with another imperative - the demand for internationalisation - and that this could be seen as an additional imperative that is embedded in the discourse of globalisation and internationalisation.

These imperatives are also not static and unchanging. We have shown ample evidence of how, for example, the demand for transformation has shifted (and has been understood to be so) from an initial focus on addressing inequity to an increasing focus on transformation as development.

In 1977 Thomas Kuhn published a book with the intriguing title The Essential Tension. This text, which followed his seminal work (1962) on the role of paradigms in science (The Structure of Scientific Revolutions), argues that in science, tradition and innovation are in tension, but that this tension is essential for science to progress. The notion (or even ideal) of tradition is captured in the notion of a paradigm that provides guidance and direction, and hence stability, to research within 'normal' periods of scientific inquiry. However, 'innovation' is equally important and necessary to ensure that science grows, and that space is created for new theories and ideas. Although there is a tension between tradition and innovation (change), the history of science has shown that this tension is an essential and productive one.

Can one make the same claim for the four imperatives of growth, efficiency, transformation and quality? Do they co-exist (in harmony) and hence co-produce the kind of doctoral educational system that the country needs? Some arguments 


\section{PART ONE • FROM THE GLOBAL TO THE LOCAL}

have been made that transformation (especially when understood as leading to more diversity) at least contributes to (or may even be an essential condition for) improved quality. In the same vein, one could argue that greater efficiency in the processes of doctoral supervision could be instrumental in achieving higher-quality doctoral graduates. However, it is equally obvious that the demand for growth can be interpreted to be in direct tension with the demands of efficiency and, especially, quality. If current trends in doctoral enrolments continue to increase, even more strain will be put on the current supervisory capacity in the system, which in turn is likely to affect the quality of the doctorate. In fact, an argument could be made that the imperatives for growth and quality are not only in tension but that they are contradictory. Achieving the one (continuous growth) undermines the achievement of the other (maintaining standards of quality), especially in a system where there are serious constraints on resources.

In an insightful overview of the origins of the doctorate in South Africa, Du Toit (2012:3) cautioned against the effects of the demands of growth on quality:

Current higher-education policy imperatives calling for a drastic increase in the overall production of the number of PhDs in South Africa will be dangerously misconceived unless serious prior consideration is given to the nature and function of the PhD degree. A substantial increase in the number of current South African PhDs by research dissertation only will most certainly not satisfy either the urgent needs for upgrading the 'academic' sector itself or the demands of the economy and society for an increased number of advanced graduates with a 'general' knowledge base and transferable intellectual skills. Instead, the most likely consequence of a substantive increase of the number of PhDs based on the current higher degrees structure is both a significant slump in academic standards as well as a probable backlash against the universities from different sectors of the economy and society: a substantial number of the new PhDs will be unable to find appropriate employment while outside institutions will remain frustrated when looking to these PhDs to satisfy their specific and general needs.

One obvious way in which the 'tension' between some of these imperatives has manifested itself in the South African university system is reflected in the differential responses to these imperatives by the different universities. We have given ample evidence of the fact that the 'response' to these demands has been very different for different universities and university groupings. The most positive changes in growth rates, efficiency and transformation are confined to a small group of eight to ten universities: the same universities that perform better on knowledge production indicators. The less productive universities in the system simply do not have the resources to respond to these imperatives. 
Hence we would argue that these four imperatives do not necessarily co-exist comfortably. There are inherent tensions and even contradictions between them. This, we believe, is one of the main reasons why any initiative to effect further change in the current system of the doctorate in the country will only result in small and incremental changes. Within a complex system whether there are counteracting (and even mutually undermining) forces at work, it is difficult to achieve anything more than small gains in efficiency or quality.

\section{DISCOURSE, IMPERATIVES AND PRACTICES}

The evidence that has been discussed in this chapter shows that there have been exceptional rates of growth in doctoral enrolments and graduates, substantial shifts in transformation (understood primarily in demographic terms), and indications of an adequately efficient system of doctoral education, but with a very inefficient postgraduate progression rate. We have discussed the data in terms of four imperatives that have shaped the doctorate in South Africa over the past 10 years. However, our thesis is not that the changes that have been recorded are simply to be understood in terms of institutional (or even individual) responses to these imperatives (and their underlying discourses).

Although there is general awareness and knowledge of these imperatives in the system (perhaps best illustrated in the general knowledge of the incentives to increase doctoral output since 2005), the changes in growth and transformation especially are clearly the result of complex interplay of demand-side factors (new demands from the labour market; the demand created by the increase in students from other African countries who choose South Africa as a destination for postgraduate students), as well as supply-side factors (new master's and PhD programme offerings, increased supervisory capacity at most universities, increased funding for doctoral studies, as well as the effect of the new incentive and reward strategies of universities).

In fact, one should be cautious not to attribute too much agency to the university sector in the face of the four imperatives. Although it is appropriate to speak of a response of the universities to some of these imperatives, this would be more applicable where the imperatives have been translated into specific funding instruments and incentives (or their counter side of penalties and sanctions). These incentives (and sanctions) operate both at the system level and the institutional level. But some of the changes that we have analysed and discussed - such as the three-fold increase in doctoral students from the rest of Africa - were probably unforeseen 15 years ago.

At the system level the introduction of the new funding framework by the Department of Higher Education and Training in 2005, which recognised the production of 
research master's and $\mathrm{PhD}$ students for additional research subsidy, has indeed elicited a clear and unequivocal 'response' from the universities. One of the reasons for this has been the fact that most universities have internalised the same incentive principles in their internal process of reward and promotion. Similarly, the National Research Foundation and other funding agencies have set very clear targets for doctoral production - especially in the case of transformation targets - that influence the research awards and grants made by the organisation. Again these principles have been appropriated by the universities (down to faculty and departmental levels) and hence have shaped individual supervisory behaviour.

But these imperatives also led to institutions adopting their own standard practices. However, these were not necessarily all in response to national imperatives. For example, most universities have established structures and initiatives to strengthen doctoral supervision (in some cases supervision training has been made compulsory) and the level of preparedness of doctoral candidates (multiple mechanisms to improve screening and selection as well as institutional support). Many universities have embarked on innovative ways to expand their supervisory capacity (changed retirement ages of staff, re-appointed productive academics, insourced external experts to act as supervisors, and so on). In general, quality assurance of the doctoral process (including examination processes) has been strengthened (in some cases this was a response to the HEQC audits of the mid-2000s), but in other cases these initiatives have gone beyond the explicit requirements of the HEQC.

In conclusion: National discourses and imperatives do not by themselves necessarily produce change. The changes in a wide variety of practices for which we have presented evidence are also the end result of the complex interplay between regional and geopolitical forces on the African continent and beyond, demand-side changes in the South African economy, as well as institutional actions - some of which are clearly responding to these imperatives, while others are self-initiated.

The future trajectory of doctoral production in South Africa will continue to be a function of this complex set of factors. And the overarching goal, we believe, should be that the imperatives of growth, efficiency and transformation always be moderated and balanced by the imperative of quality. It remains a non-negotiable: we must actively and consistently nourish the highest criteria of excellence in doctoral production. 


\section{CHAPTER 4 - THE DOCTORATE IN SOUTH AFRICA - TRENDS, CHALLENGES AND CONSTRAINTS}

\section{REFERENCES}

ASSAf (Academy of Science for South Africa). 2010. The PhD study: An evidence-based study on how to meet the demands for high-level skills in an emerging economy. Pretoria: ASSAf.

ASSAf (Academy of Science for South Africa). 2011. Consensus study on the state of the humanities in South Africa: Status, prospects and strategies. Pretoria: ASSAf.

Badat S. 2004. Transforming South African higher education 1990-2003: Goals, policy initiatives and critical challenges. In: N Cloete, P Pillay, S Badat \& T Moja. National policy and a regional response in South African higher education. Cape Town: David Philips. $1-50$.

Botha J. 2015. A desktop study of higher education tracer studies in South Africa. Research Report: CREST: Stellenbosch University.

Castells M. 1991. The university system: Engine of development in the new world economy. Paper for the World Bank seminar on higher education and development.

Castells M \& Calderón. 2013. Development, democracy and social change in Chile. In: M Castells \& P Himanen (eds). Reconceptualizing development in the global information age. Oxford: Oxford University Press. 175-204.

Castells M \& Cloete N. 2011 . Informational development and human development: South Africa in a global context. Paper for Stellenbosch Institute for Advanced Study seminar, Stellenbosch.

Castells M \& Himanen P (eds). 2014. Reconceptualising development in the global information age. Oxford: Oxford University Press.

Castells M. 2001. Universities as dynamic systems of contradictory functions. In: J Muller, N Cloete \& S Badat (eds). Challenges of globalisation: South African debates with Manuel Castells. Cape Town: Maskew Miller Longman. 206-224.

CHE (Council on Higher Education). 2000. Towards a new higher education landscape: Meeting the equity, quality and social development imperatives of South Africa in the 21 st century. Pretoria: Council on Higher Education.

CHE (Council on Higher Education). 2002. A new academic policy for programmes and qualifications in higher education. Pretoria: Council on Higher Education.

CHE (Council on Higher Education). 2004. HEQC criteria for programme accreditation. Pretoria: Council on Higher Education.

CHE (Council on Higher Education). 2008. HEQC framework for delegated functions. Available at www.che.ac.za/media_and_publications/frameworks-criteria/heqcframeworkdelegated-functions

Cloete N \& Gillwald A. 2014. South Africa: Informational development and human development - Rights vs capabilities. In: M Castells \& P Himanen (eds). Reconceptualizing development in the global information age. Oxford: Oxford University Press. 140-174.

Cloete N. 2014a. A new look at demographic transformation: Comments on Govinder et al. South African Journal of Science, $110(1 / 2)$. [Retrieved 24 March 2014] http://www.sajs. co.za/new-lookdemographic-transformation-comments-govinder-et-al-2013/nico-cloete

Cloete N. 2014b. The South African higher education system: Performance and policy. Studies in Higher Education, 39(8): 1355-1368. 


\section{PART ONE • FROM THE GLOBAL TO THE LOCAL}

Cloete N, Mouton J \& Sheppard C. 2015. Doctoral education in South Africa: Policy, discourse and data. Cape Town: African Minds.

Council of Graduate Schools. 2004. PhD completion and attrition: Numbers, leadership, and next steps. Washington DC: Council of Graduate Schools.

Council of Graduate Schools. 2008. PhD completion and attrition: Analysis of baseline demographic data from the PhD completion project. [Retrieved 11 September 2013] www.phdcompletion.org/quantitative/book1_quant.asp

CREST (Centre for Research on Evaluation, Science and Technology). 2014. DST retention and progression study. Research Report: CREST: Stellenbosch University.

DHET (Department of Higher Education and Training). 2012. Green Paper for Post-School Education and Training. Pretoria: Department of Higher Education and Training.

DHET (Department of Higher Education and Training). 2013a. Higher Education Management Information System (HEMIS), 2000-2012. Pretoria: Government Publishers.

DHET (Department of Higher Education and Training). 2013b. PhD cohort analyses. Higher Education Management Information System (HEMIS), 2000-2013. Pretoria: Department of Higher Education and Training.

DHET (Department of Higher Education and Training). 2014a. Policy Framework on Differentiation in the South African Post-School System. Pretoria: Department of Higher Education and Training.

DHET (Department of Higher Education and Training). 2014b. White Paper for Post-school Education and Training: Building an expanded effective and integrated post school system. Government Notice 37229 of 2014. Pretoria: Department of Higher Education and Training.

DHET (Department of Higher Education and Training). 2015. Research Policy 2015. Government notice No. 188. 11 March 2015. Pretoria: Government Printer.

DHET (Department of Higher Education and Training) and CHE (Council on Higher Education). 2014. HEMIS. PhD cohort analysis. Pretoria: Department of Higher Education and Training.

DNO (Departement van Nasionale Opvoeding). 1982. Statistiek van kwalifikasies toegeken deur die outonome universiteite in die jare 1971-1979. Pretoria: Government Publishers.

DoE (Department of Education). 1997. Education White Paper 3: A Programme for the transformation of higher education. (General Notice 1196 of 1997.) Pretoria: Government Publishers.

DoE (Department of Education). 1999. South African Post-Secondary Education (SAPSE) Information System. Pretoria: Government Publishers.

DoE (Department of Education). 2001. National Plan for Higher Education. Pretoria: Ministry of Education. Available at http://chet.org.za/manual/media/files/chet_hernana_docs/ South\%20Africa/National/National\%20Plan\%20for\%20HE\%20SA.pdf [accessed 8 October 2015] 
DoE (Department of Education). 2005a. Minimum admission requirements for Higher Certificate, Diploma and Bachelor's Degree Programmes requiring a National Senior Certificate. Available at www.education.gov.za/Documents/policies/ AdmissionRequirements.pdf [accessed 25 June 2009]

DoE (Department of Education). 2005b. The National Senior Certificate: A qualification at level 4 on the National Qualifications Framework (NQF). Available at www.education.gov. za/Documents/policies/NSCNQF4.pdf [accessed 25 June 2009]

DoE (Department of Education). 2005c. Student Enrolment Planning in Public Higher Education. Pretoria: Department of Education.

DoF (Department of Finance). 1996. Growth, employment, and redistribution (GEAR) macroeconomic policy in 1996. Pretoria: Department of Finance.

DST (Department of Science and Technology). 2008. Innovation Towards a Knowledge-Based Economy. Ten-Year Innovation Plan 2008-2018. Pretoria: Government Publishers.

Du Toit A. 2012. The PhD and the degree structure of South African higher education: A brief and rough guide. Paper presented at the CHET seminar 'Knowledge Production in South African Higher Education', 23 February 2012. [Retrieved 8 October 2015] http://www. chet.org. za/papers/phd-and-degree-structure-south-african-higher-education

Garbers JG. 1960. Gradueringstendense in Suid-Afrika 1918-1957. Doctoral thesis. Pretoria: University of Pretoria.

Govinder KS, Zondo NP \& Makgoba MW. 2013. A new look at demographic transformation for universities in South Africa. South African Journal of Science, 109(1 1/12).

Govinder KS, Zondo NP \& Makgoba MW. 2014. Taking the transformation discourse forward: A response to Cloete, Dunne and Moultrie and Dorrington. South African Journal of Science, 110(3/4).

Griesel H \& Parker B. 2008. Graduate attributes: A baseline study on South African graduates from the perspective of employers. Pretoria: Higher Education South Africa.

Knight R. 2001. South Africa: Economic policy and development. [Retrieved 1 September 2013] http:// richardknight.homestead.com/files/sisaeconomy.htm

Kraak A. \& Du Toit J. 2013. Pathways from university to work: A graduate destination survey of the 2010 cohort of graduates from Western Cape universities. Cape Town: Cape Higher Education Consortium.

Kuhn TS. 1962. The structure of scientific revolutions. Chicago: Chicago University Press.

Kuhn TS. 1977. The essential tension: Selected studies in scientific tradition and change. Chicago: Chicago University Press.

Mouton J \& Hunter M. 2003. 'n Ondersoek na die stand van nagraadse studie aan die Universiteit van Stellenbosch. Unpublished report. Centre for Interdisciplinary Studies, Stellenbosch University.

Mouton J, Boshoff N \& Ritter M. 2010. Survey of doctoral graduates. A destination study of PhD students across a sample of fields and institutions. A report commissioned by ASSAf. Stellenbosch: Centre for Research on Science and Technology, Stellenbosch University.

Mouton J. 2011 . Doctoral production in South Africa: Statistics, challenges and responses. Perspectives in Education, 29(3): 13-29. 


\section{PART ONE • FROM THE GLOBAL TO THE LOCAL}

Mouton J, Boshoff N \& James M. 2015. A survey of doctoral supervisors in South Africa. South African Journal of Higher Education, 29(2): 1-22.

National Science Foundation. 2012. Chapter 2: Higher education in science and engineering. [Retrieved 15 August 2013] http://www.nsf.gov/statistics/seind 12/c2/c2h.htm

NCHE (National Commission on Higher Education). 1996. A framework for transformation. Pretoria: National Commission on Higher Education.

NPC (National Planning Commission). 2012. National Development Plan 2030: Our future, make it work. [Retrieved 8 October 2015] http://www.poa.gov.za/news/Documents/ NPC\%20National\%20 Development\%20Plan\%20Vision\%202030\%20-lo-res.pdf

NPC (National Planning Commission). 2011 . National Development Plan: Vision for 2030. [Retrieved 8 October 2015] http://www.gov.za/sites/www.gov.za/files/devplan_2.pdf 